\title{
A Study on Marketing Behaviour of Tomato Growers in Shivpuri District M.P, India
}

\author{
Sonare Rashmita*, Bihare Govinda and Singh Arvind \\ Department of Agriculture Extension Education, College of Agriculture, \\ Gwalior-474002, India \\ *Corresponding author
}

Keywords

Respondent,

Tomato growers,

simple random

sampling and

Mediator

Article Info

Accepted:

14 May 2020

Available Online:

10 June 2020
The present study was carried out in Shivpuri district (M.P.) due to the maximum area (8145 ha) and production (252495 MT) of tomato in this district. There are 8 blocks of Shivpuri district out of which 3 blocks were selected on the basis of maximum area and production.120 respondents were selected with the help of simple random sampling without random sample. Objective of this study is to study the Marketing behavior of tomato growers. marketing behavior that consumers display in searching for, purchasing, selling, using, evaluation and disposing of products and services that they expect will satisfy their needs. The study revealed that majority of the respondents $(75 \%)$ had medium level of overall marketing behaviour followed by low (18.3\%) and only 6.7 per cent had high level of marketing behavior.

\section{Introduction}

Tomato known scientifically as Solanum lycopersicum is one of the important and popular vegetables and plays an important role in balanced nutrition. Tomatoes are major source of antioxidant lycopene, which has been linked to many health benefits, including reduced risk of heart disease and cancer. They are also a great source of vitamin C, potassium, folate, and vitamin $\mathrm{K}$. The water content of tomatoes is around 95 per cent. The other 5 per cent consist mainly carbohydrates and fiber. The annual production of tomatoes 20 million tonnes in the country, Madhya Pradesh is leader in tomato production in India, with $15.75 \%$ of the total production.

There is a huge potential for processing Industry in Madhya Pradesh due to the high volume of the harvest, which becomes financially attractive from an investment point of view. Besides the volume cost benefits, the state government is also giving attractive 
investment benefits to potential investors. Processing of Tomato: Puree, Dehydration, Ketchup (Powder and cut piece).

\section{Materials and Methods}

This study was carried out in Shivpuri district of Madhya Pradesh. Shivpuri district is situated in the central India state of M.P. due to the maximum area (8145 ha) and production (252495 MT) of tomato in this district. 8 blocks come under Shivpuri district out of which 3 blocks (Pohari, Kolaras and Shivpuri) were precast on the basis of maximum area and production. 120 respondents were selected with the help of simple random sampling without random sample. primary data were gathered from the respondents by using the semi structured interview schedule, which was pretested before actual applications. In order to understand the farmer well and answer, Hindi was used in the interview Schedule. the knowledge 3 for complete, 2 for partial and 1 for low knowledge of each practice was assigned.

\section{Results and Discussion}

The study of dependent variable was made with reference to marketing behaviour of tomato growers. The table 1 shows that the reason to sell at any time, majority of the respondents (93.33\%) had lack of cold storage followed by domestic financial requirement (90.83\%), to repay the loan $(68.33 \%)$, lack of quality (44.17\%) and 40 per cent of the respondents had due to being highly destructive.

In the case of want to sell tomato, majority of the respondents $(80 \%)$ expressed that they sold their produce to directly sell to the wholesaler followed by sold their produce directly to the cooperative committee $(38.33 \%)$, to the middleman (30.83\%) through the commission agent and to the retail salesperson $(7.5 \%)$.

Table.1 Distribution of tomato growers according to their marketing behavior

\begin{tabular}{|c|l|c|c|}
\hline S. No. & Category & frequency & \% \\
\hline 1. & Reason to sell tomato at any time & 48 & 40.00 \\
a & Due to being highly destructive & 53 & 44.17 \\
b & Lack of quality & 112 & 93.33 \\
c & Lack of cold storage & 109 & 90.83 \\
d & Domestic financial requirement & 82 & 68.33 \\
\hline e & To repay the loan & & \\
\hline 2. & Whom do you want to sell your tomato? & 09 & 7.50 \\
a & Retail salesperson & 96 & 80.00 \\
b & Wholesales & 37 & 30.83 \\
c & Middleman & 46 & 38.33 \\
d & Cooperative committee & 115 & 95.83 \\
\hline 3. & The reason for selling tomato at a certain place & 105 & 87.50 \\
a & Good sale & 95 & 79.17 \\
b & Good transportation facility & 35 & 29.17 \\
c & Get good value & 57 & 47.50 \\
\hline d & Business facility availability & & \\
e & Lack of mediator & & \\
\hline
\end{tabular}


Table.2 Distribution of the tomato growers according to their overall marketing behavior of recommended cultivation practices of tomato $(n=120)$

\begin{tabular}{|l|c|c|}
\hline Overall level of marketing behavior & frequency & Percentage \\
\hline Low (<7.01 Score) & 22 & 18.30 \\
\hline Medium (7.01- 11.71 Score) & 90 & 75.00 \\
\hline High (> 11.71 Score) & 08 & 6.70 \\
\hline Mean= 9.36SD= 2.35 & & \\
\hline
\end{tabular}

Finally, the reason for selling tomato at a certain place; majority of the respondents $(95.83 \%)$ had good sale, followed by good transport facility $(87.5 \%)$, get good value $(79.17 \%)$, lack of mediators $(47.5 \%)$ and business facility availability $(29.17 \%)$.

\section{Overall marketing behavior of tomato growers}

Marketing behavior that consumers display in searching for, purchasing, selling, using, evaluation and disposing of products and services that they expect will satisfy their needs. It is obvious from the Table 2, majority of the respondents $(75 \%)$ had medium level of overall marketing behaviour followed by low $(18.3 \%)$ and only 6.7 per cent had high level of marketing behaviour.

Majority of the respondents had medium level of marketing behavior.majority of the respondents $(75 \%)$ had medium level of overall marketing behaviour followed by low $(18.3 \%)$ and only 6.7 per cent had high level of marketing behaviour.

\section{References}

Bisnoi, Sisodiya, Sharma and Kumar (2017) Knowledge of Farmers about Improved Bt Cotton Production Technology Indian Journal of Extension Education 53 (4):121-123.

Chaudhary, jha, Sarkar and Singh (2017) Impact of Jharkhand Department of Agriculture on Knowledge, Attitude and
Adoption of the Farmers. Indian Journal of Extension Education 53 (4):1-6.

Dambazau, S.A.,Srivastava, J. P. And Tajudeen,A. (2015). Communication behavior of potato growers. Journal of Communication Studies, XXXIII (2):48-55.

Devde Pradip Uddhavarao (2017). Marketing behaviour of vegetable growers. $M$. Sc. (Agri.) Thesis Vasantrao Naik Marthwada Krishi Vidyapeeth, Parbhani.

Kashinath, Lal, Kumar, Kapoor, Basantia, Meena, Poul, ahmad, Roy and Kundu (2018). Knowledge Level of North Andaman Farmers towards Scientific Vegetable Cultivation Practices. Indian Journal of Extension Education 54 (2):256-260.

Lenin, V. (2012). Knowledge Level of Farmers on Organic Farming in Tamil Nadu.Indian Res. J. Ext. Edu. 12 (3):8994.

Patel Sheetal, Choudhary Sandhya, Wankhede Abhay, Swarnakar V.K. (2017). Knowledge \& adoption behaviour of flower growers under NHM in Ujjain district of Madhya Pradesh. International Journal of information research. 4 (11): 18471852.

Singh, P. Choudhary, Meenakshi and Lakhera, J.P. (2014). Knowledge and Attitude Farmers towards Improved Wheat Production Technology. Indian Res. J. Ext. Edu. 14 (2): 54-59. 


\section{How to cite this article:}

Sonare Rashmita, Bihare Govinda and Singh Arvind. 2020. A Study on Marketing Behaviour of Tomato Growers in Shivpuri District, M.P, India. Int.J.Curr.Microbiol.App.Sci. 9(06): 331334. doi: https://doi.org/10.20546/ijcmas.2020.906.043 